\title{
High level expression of Acidothermus cellulolyticus $\beta-1$, 4-endoglucanase in transgenic rice enhances the hydrolysis of its straw by cultured cow gastric fluid
}

\author{
Hong Li Chou', Ziyu Dai ${ }^{2}$, Chia Wen Hsieh ${ }^{3}$ and Maurice SB Ku ${ }^{1,4^{*}}$
}

\begin{abstract}
Background: Large-scale production of effective cellulose hydrolytic enzymes is the key to the bioconversion of agricultural residues to ethanol. The goal of this study was to develop a rice plant as a bioreactor for the largescale production of cellulose hydrolytic enzymes via genetic transformation, and to simultaneously improve rice straw as an efficient biomass feedstock for conversion of cellulose to glucose.

Results: In this study, the cellulose hydrolytic enzyme $\beta$-1, 4-endoglucanase (E1) gene, from the thermophilic bacterium Acidothermus cellulolyticus, was overexpressed in rice through Agrobacterium-mediated transformation. The expression of the bacterial E1 gene in rice was driven by the constitutive Mac promoter, a hybrid promoter of Ti plasmid mannopine synthetase promoter and cauliflower mosaic virus 355 promoter enhancer, with the signal peptide of tobacco pathogenesis-related protein for targeting the E1 protein to the apoplastic compartment for storage. A total of 52 transgenic rice plants from six independent lines expressing the bacterial E1 enzyme were obtained that expressed the gene at high levels without severely impairing plant growth and development. However, some transgenic plants exhibited a shorter stature and flowered earlier than the wild type plants. The E1 specific activities in the leaves of the highest expressing transgenic rice lines were about 20-fold higher than those of various transgenic plants obtained in previous studies and the protein amounts accounted for up to $6.1 \%$ of the total leaf soluble protein. A zymogram and temperature-dependent activity analyses demonstrated the

thermostability of the E1 enzyme and its substrate specificity against cellulose, and a simple heat treatment can be used to purify the protein. In addition, hydrolysis of transgenic rice straw with cultured cow gastric fluid for one hour at $39^{\circ} \mathrm{C}$ and another hour at $81^{\circ} \mathrm{C}$ yielded $43 \%$ more reducing sugars than wild type rice straw.

Conclusion: Taken together, these data suggest that transgenic rice can effectively serve as a bioreactor for the large-scale production of active, thermostable cellulose hydrolytic enzymes. As a feedstock, direct expression of large amount of cellulases in transgenic rice may also facilitate saccharification of cellulose in rice straw and significantly reduce the costs for hydrolytic enzymes.
\end{abstract}

\section{Background}

In facing increasing demands for energy and depleting fossil oil reserve, the adoption of alternative, renewable energy is imperative. In the past decade, utilization of biomass for fuel production has been considered not only practical but also extremely vital with respect to the

\footnotetext{
* Correspondence: mku@mail.ncyu.edu.tw

'Institute of Bioagricultural Science, National Chiayi University, Chiayi, 60004 Taiwan

Full list of author information is available at the end of the article
}

development of sustainable energy [1-3]. Biofuels converted from biomass, considered renewable, environment friendly and carbon neutral, will serve a more important function in the days to come. Although the production of biofuels from starch, sugar or oil from traditional food crops, such as corn, sugarcane, soybean and canola, is relatively simple, it competes with human beings and animals for foods and requires a high energy input for cultivation of these crops. Use of lignocellulosic crops or agricultural residues, such as rice straw or corn stover, for ethanol
C Biomed Central

() 2011 Chou et al.; licensee BioMed Central Ltd. This is an open access article distributed under the terms of the Creative Commons Attribution License (http://creativecommons.org/licenses/by/2.0), which permits unrestricted use, distribution, and reproduction in any medium, provided the original work is properly cited. 
production is not only economical (high energy output to input ratio) but also environment friendly (that is, carbon neutral and with the emission of less toxic pollutants) and will curtail our reliance on fossil oil and help prevent global warming [4].

Lignocellulose is the major polysaccharide component of global plant mass, which consists of hemicellulose, lignin and cellulose, a polymer of thousands of $1,4-\beta$ linked unions of D-glucose $[5,6]$. The polymer is arranged in collinear, semi-crystalline bundles and it comprises up to $45 \%$ of the dry weight of plant biomass, which is a potentially inexpensive, renewable source of fermentable glucose $[7,8]$. Rice is one of the most important food resources in the world, and global rice production has risen steadily from about 200 million metric tons in 1960 to over 660 million metric tons in 2009 [9]. At the same time, about 800 million metric tons of rice straw is also produced annually, which is normally burned or decayed in the field, producing more pollutants and greenhouse gases (for example, methane). Thus, developing rice as a dual-functional crop for solving both the immediate food and energy crisis issues could pave the road toward the successful development of sustainable energy and the prevention of possible pollution from agricultural wastes. However, the conversion of the polysaccharide component of lignocellulose into ethanol for use as an alternative transportation fuel and other useful chemicals requires a series of complete pretreatment and hydrolysis procedures $[2,6,10]$. The complete hydrolysis of cellulose (saccharification) requires at least three different hydrolytic enzymes, including $\beta$-1,4-endoglucanse (EC 3.2.1.4), $\beta-1$, 4-exoglucanse (EC 3.2.1.91), and $\beta$-D-glucosidase (EC 3.2.1.21) $[2,10,11]$.

Large-scale production of effective cellulose hydrolytic enzymes is the key to the bioconversion of lignocellulose to fermentative sugars for biofuel and chemical production. Nowadays, production costs and the performance of hydrolytic enzymes from bacterial and fungal sources for cellulosic ethanol production remain the major obstacles because the essential nutrients and the maintenance of optimal conditions are very expensive and laborious $[3,12]$. Nevertheless, there has been significant progress in bringing effective and inexpensive means of cellulase production from a large scale bioreactor, in the conversion of low value lignocellulosic material into a cost effective fermentative sugars for producing biofuels. Replacing microorganisms with transgenic plants for the production of cellulose hydrolytic enzymes will significantly reduce the production costs. In other words, manufacturing heterologous cellulases in plants (especially in energy crops) using genetic engineering would lower the expense associated with enzyme production and the amount of enzyme loading required during saccharification $[11,13]$. So far, a number of studies have attempted to express cell wall-related degrading enzymes in transgenic plants, such as $\beta$-glucosidases $[14,15]$, ferulic acid esterases [16,17], xylanases [18], cellobiohydrase $[19,20]$ and endoglucanase $[7,21-26]$. However, there may be a trade off between expressing foreign cellulases in transgenic plants, obstructing their normal growth [11] and low level expression [27,28]. Hence, it is essential to design a proper expression system for the production of plants expressing microbial cellulases, without perturbing their growth and development. This system needs to include a strong promoter with a high-level transcription capacity and an appropriate signal peptide to target the foreign protein into a suitable compartment for high level accumulation [21].

A. cellulolyticus E1 endoglucanase is a well-known thermostable enzyme, which exhibits low activity at ambient temperatures $[21,22,29]$. This desirable E1 feature might have less deleterious effects on the growth and development of transgenic plants under normal growth conditions. Transgenic expression of thermostable E1 endoglucanase has been examined in Arabidopsis, potato, maize, rice and tobacco [7,21-25], with the foreign protein accounting for up to $0.01 \%$ to approximately $25.7 \%$ of the total soluble protein, depending on the host plant and its tissue. In addition, when expressed in plants, the E1 enzyme exhibits high temperature stability (optimum $81^{\circ} \mathrm{C}$ ) and relatively low activity at general room temperatures [21].

The major objective of this study was to express and accumulate $A$. cellulolyticus E1 in the apoplastic compartment of rice in large quantities. The expression of the bacterial E1 gene in rice was under the control of the strong constitutive Mac promoter, which has been previously shown to have three- to five-fold higher strength than the cauliflower mosaic virus $35 \mathrm{~S}$ promoter [30], and targeted the E1 protein to the apoplast compartment for higher accumulation. We report that high expression levels of active E1 enzyme were achieved in transgenic rice plants, which accumulated up to $6.1 \%$ of total leaf soluble protein. Moreover, this thermostable enzyme can be purified from crude extract by a simple heat treatment. In addition, digestion of transgenic rice straw with cultured cow gastric fluid (CGF) for one hour at $39^{\circ} \mathrm{C}$ and another hour at $81^{\circ} \mathrm{C}$ yielded $43 \%$ more reducing sugars than the wild type rice straw. Thus, the present study demonstrates the technical feasibility and great potential to reduce the cost of producing cell wall-degrading enzymes from transgenic crops.

\section{Results}

Rice transformation and transgene confirmation

The A. cellulolyticus E1 and hygromycin phosphotransferase II (HptII) genes in the $p 1500$ binary vector were 
successfully introduced into rice genome by Agrobacterium-mediated transformation. Fourteen independent T0 transgenic lines with a total of 84 transgenic plants were obtained for an E1 activity assay. Most transgenic plants exhibited a normal phenotype and fertility. Noticeably, some transgenic rice plants with high levels of expression tended to have a shorter stature and flowered one week earlier than the wild type rice plants. One rice plant from each line was chosen to obtain self-pollinated seeds. Sixty T1 seeds from each line were germinated on 1/2 Murashige and Skoog medium containing $50 \mathrm{mg} / \mathrm{L}$ hygromycin, from which six lines exhibited a germination ratio of approximately three to one $(48: 12,45: 15$, $43: 17,47: 13,44: 16$ and 47:13), indicating one copy of HptII gene insertion in these lines. For each line, all hygromycin-resistant plants were transplanted to soil and grown in the greenhouse for further characterization in terms of Elexpression. Southern blotting analysis with the T0 plants of the six transgenic lines that showed a 3:1 germination ratio of T1 seeds in hygromycin medium confirmed the single-copy insertion in all six transgenic lines, except transgenic line \#4 that only contained the HptII gene (Figure 1).

\section{E1 gene expression in transgenic rice}

Northern blot analysis of the $E 1$ transcript, of a predicted $1.75 \mathrm{~kb}$ mRNA, was also detected in leaf tissues of all transgenic lines, except line \#4 and the wild type plant (Figure 2). These results demonstrate that the integrated $E 1$ gene from A. cellulolyticus can be properly transcribed in rice. Although the Mac promoter is expected to drive constitutive expression of $E 1$ gene in transgenic plants, the gene was expressed in a somewhat organ-specific manner, with the highest levels of transcript being detected in the leaf and the lowest levels in the root (Figure 3).

The level of E1 protein accumulated in leaves among different transgenic lines and various organs was assessed by western blotting analysis (Figure 4). Rabbit antibody raised against E1 enzyme detected the protein in the leaves of five of the six transgenic rice lines, with the molecular mass of approximately $38 \mathrm{kDa}$, which corresponds to the catalytic domain of endoglucanase E1 (Figure 4A). The highest level of E1 accumulation was found in transgenic line \#3, while no E1 protein was detected in the wild type rice plant and transgenic line \#4. Furthermore, a substantial amount of E1 protein was accumulated in green floret, leaf, stem and root when compared on a protein basis, with a small amount accumulated in the mature seed (Figure 4B).

\section{Thermostability of the E1 protein and purification}

The profiles of total leaf soluble protein for the wild type and six transgenic lines were examined by SDS-

\section{(A) HpttII}

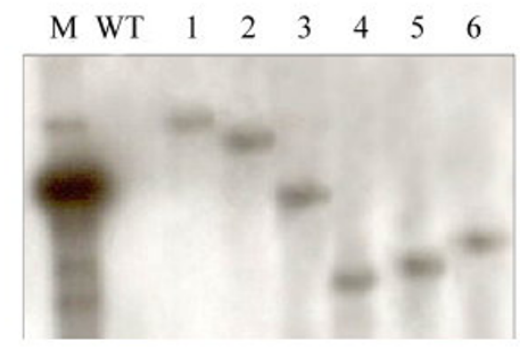

(B) $E 1$

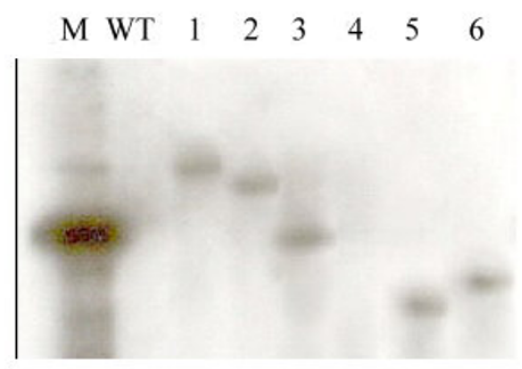

Figure 1 Southern blot analysis of Hptll and E1 genes. Genomic DNA was extracted from six independent T0 transgenic lines (\#1 to \#6) and wild type (WT) rice plants, digested with Hindlll, separated by agarose gel electrophoresis, transferred to nylon membrane and hybridized with (A) Hptll probe or (B) E1 probe. Note that E1 gene was not detected in transgenic line \#4 and wild type rice plants.

(A) $E 1$

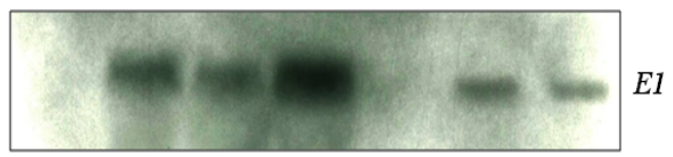

(B) rRNA

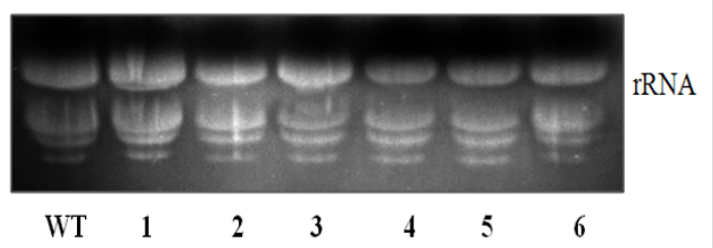

Figure 2 Northern blot analysis of E1 gene transcript in the leaves. Twenty-five micrograms of total RNA, extracted from the leaves of six independent T0 transgenic lines (\#1 to \#6) and wild type (WT) rice plants, was loaded into each lane, transferred to nylon membrane after electrophoresis and probed with (A) E1 DNA or (B) stained for rRNA by EtBr. Note that no E1 gene transcript was detected in transgenic line \#4 and wild type plants. 
(A) $E 1$

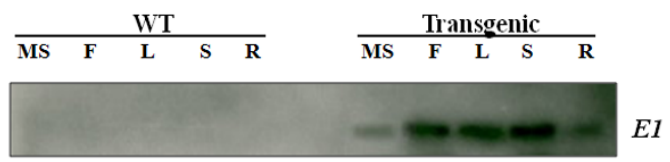

(B) rRNA

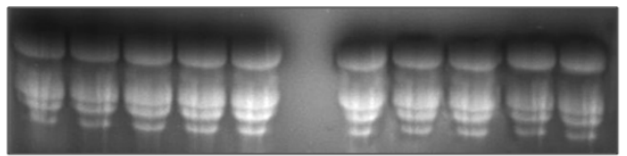

rRNA

Figure 3 Tissue-specific expression of $E 1$ gene, as analyzed by northern blot analysis. Twenty-five micrograms of total RNA, extracted from mature seed (MS), green floret $(F)$, leaf $(L)$, stem $(S)$, and root (R) of T0 transgenic line \#3-5 (one of the T0 plants of transgenic line \#3) and wild type (WT) rice plants, was loaded into each lane, transferred to nylon membrane after electrophoresis and probed with (A) El DNA or (B) stained for rRNA by EtBr.

PAGE and staining with Coomassie Brilliant Blue (Figure 5). Figure 5A shows the profiles of the soluble protein after being boiled for two minutes in a buffer containing $\beta$-mercaptoethanol and SDS. As anticipated,

(A)

(a) $\mathrm{E} 1(38 \mathrm{kD})$

\begin{tabular}{|lllllllllll}
$M$ & WT & 1 & 2 & 3 & 4 & 5 & 6 & $M$ \\
\hline & & & & & & & & & &
\end{tabular}

(b) $\operatorname{Rbc~L~(56~kD)~}$

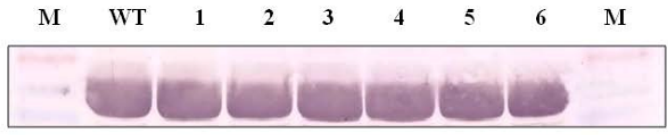

(B)

E1 (38 kD)

\begin{tabular}{|c|c|c|c|c|c|c|c|}
\hline \multirow[t]{2}{*}{ M } & \multirow[t]{2}{*}{ WT } & \multicolumn{5}{|c|}{ Transgenic } & \multirow[t]{2}{*}{ M } \\
\hline & & MS & $\bar{F}$ & $\mathbf{L}$ & $\mathrm{s}$ & R & \\
\hline $\cos$ & & & & & & 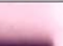 & - \\
\hline 10 & & & & & & & ene \\
\hline-6 & & & & & & & wet \\
\hline
\end{tabular}

Figure 4 Western immunoblot analysis of E1 and Rubisco large subunit proteins in the leaf and different organs. Total soluble protein was extracted from the leaves of six independent T0 transgenic lines (\#1 to \#6) and wild type (WT) rice plants and from the mature seed (MS), green floret $(F)$, leaf $(L)$, stem $(S)$ and root $(R)$ of T0 transgenic line \#3-5, separated by SDS-PAGE, transferred to polyvinylidene fluoride membrane and probed with polyclonal antibodies against (A) E1 or (B) Rubisco large subunit. Twenty micrograms of protein was loaded per lane. Note that E1 protein was not detected in the leaves of transgenic line \#4 and wild type rice plants.
(A) No heat pretreatment

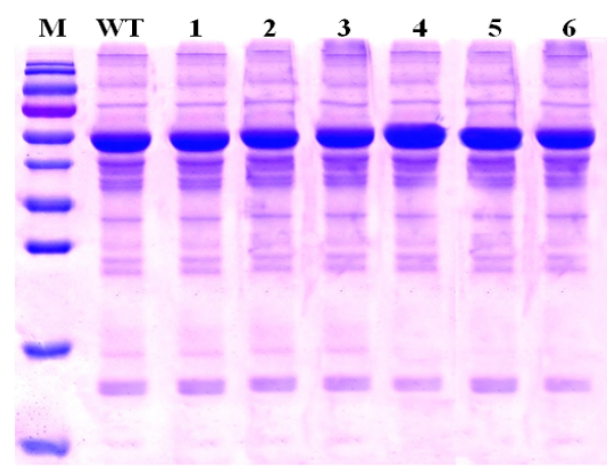

(B) With heat pretreatment $\left(78^{\circ} \mathrm{C}, 45 \mathrm{~min}\right)$

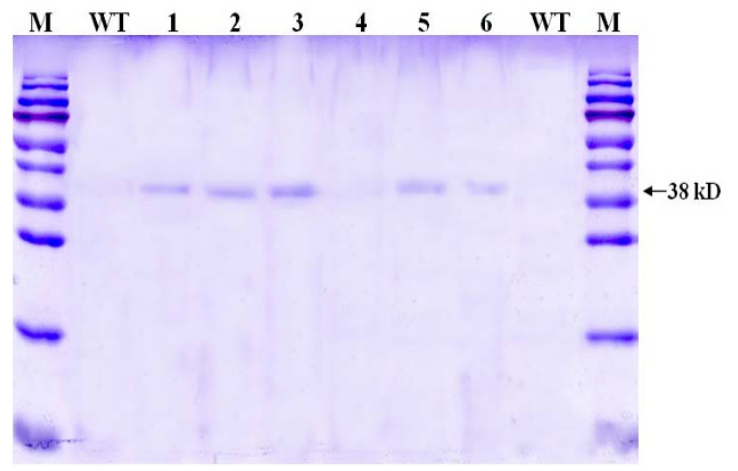

Figure 5 SDS-PAGE analysis of leaf soluble protein with or without prior heat pretreatment. Total leaf soluble protein was extracted from newly matured leaves of six independent T0 transgenic (\#1 to \#6) and wild type (WT) rice plants (A) without or (B) with prior heat treatment at $78^{\circ} \mathrm{C}$ for 45 min before electrophoretic separation by SDS-PAGE. Twenty micrograms of protein was loaded per lane. M: protein standards. After electrophoresis, gels were stained with Coomassie Brilliant Blue R250.

after separation by SDS-PAGE the most abundant proteins in the leaf samples were Rubisco large $(56 \mathrm{kDa})$ and small $(14 \mathrm{kDa})$ subunits. As E1 is a thermostable enzyme, it should be more stable than the majority of other plant proteins under heat treatment $[7,25,26,29]$. When the leaf protein extracts of transgenic lines \#1, $\# 2$, \#3, \#5 and \#6, which contained the A. cellulolyticus $E 1$ gene, were subjected to a heat pretreatment and centrifugation, the $38 \mathrm{kDa}$ E1 polypeptide corresponding to the E1 catalytic domain was the major protein left in the samples (Figure 5B). No detectable E1 protein was left in the heat-treated leaf protein samples of the wild type plant or transgenic line \#4. Consequently, based on this feature, E1 protein can be easily purified from the 
tissues of transgenic rice plants by this simple and rapid procedure.

\section{Enzymatic activity and zymogram analysis of E1 protein} The enzymatic activities of $\mathrm{E} 1$ in the leaf extracts of different primary (T0) rice transformants are shown in Figure 6A. A wide range of activity was detected among the five transgenic lines containing the $E 1$ gene. As expected, both the wild type plant and transgenic line \#4 had very little endoglucanase activity. In accordance with the results of northern blot and western immunoblot analyses, transgenic line \#3 exhibited the highest E1 activity of over 22,000 $\mathrm{pmol} \mathrm{MU} / \mathrm{mg}$ protein/min, while line \#6 also yielded very high E1 activities (17,500 pmol MU/mg protein $/ \mathrm{min}$ ). The E1 activities of the other three lines were only about one tenth the levels of transgenic lines \#3 and \#6. The activity of A. cellulolyticus E1 in different plant tissues was also examined and ranged from $18,000 \mathrm{pmol}$ $\mathrm{MU} / \mathrm{mg}$ protein/min to $25,000 \mathrm{pmol} \mathrm{MU} / \mathrm{mg}$ protein/min (Figure 6B). Furthermore, after germination of seeds derived from the self-pollination of $\mathrm{T} 0$ transgenic plants on hygromycin-containing medium, the E1 activity was examined in the leaves of 15 randomly selected T1 plants from each line. The activity data for transgenic line \#3-5 (one of the T0 plants of transgenic line \#3 that possesses the highest enzyme activity) and its own next generation T1 plants (\#3-5-1 to \#3-5-15) can be grouped into two classes based on the E1 activity phenotype: 10 plants with E1 activities similar to that of T0 plants (hemizygous), and five plants with $\mathrm{E} 1$ activities about twice that of T0 plants (homozygous) (Figure 6C). The data for the other five lines also showed a similar segregation pattern (data not shown). Thus, the T1 plants segregated into a 2:1 ratio for E1 activity phenotype, in agreement with the notion that the $A$. cellulolyticus $E 1$ gene was present in the genome of transgenic plants in one copy (Figure 1). The E1 specific activities in the leaves of homozygous plants of transgenic line \#3 ranged from 55,000 $\mathrm{pmol} \mathrm{MU} / \mathrm{mg}$ protein/min to $79,000 \mathrm{pmol} \mathrm{MU} / \mathrm{mg}$ protein/min.

A zymogram with native PAGE was applied to test the leaf E1 activity by digesting carboxymethyl cellulose (CMC) in situ. As shown in Figure 7, a single clearance band was detected for transgenic line \#1, \#2, \#3, \#5 and \#6, but not in the wild type and transgenic line \#4, clearly indicating the digestion of CMC by the $38 \mathrm{kDa}$ endoglucanase after incubation of the gel at $65^{\circ} \mathrm{C}$ for $30 \mathrm{~min}$. Again, transgenic lines \#3 and \#6 also showed the highest CMC digestion activities; the related amounts of E1 protein ranged from $0.8 \%$ in transgenic line $\# 1$ to $6.1 \%$ of the total leaf soluble protein in transgenic line \#3.

\section{Enzymatic hydrolysis of rice straw with cultured CGF}

To test if transgenic rice straw expressing the bacterial E1 protein could be more efficient in producing
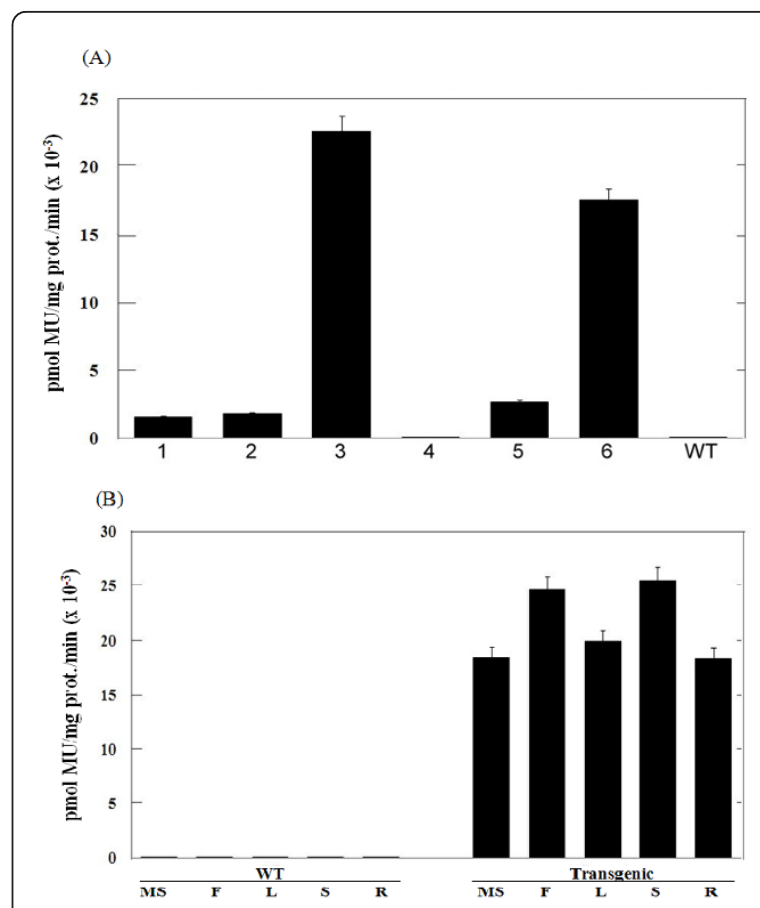

(C)

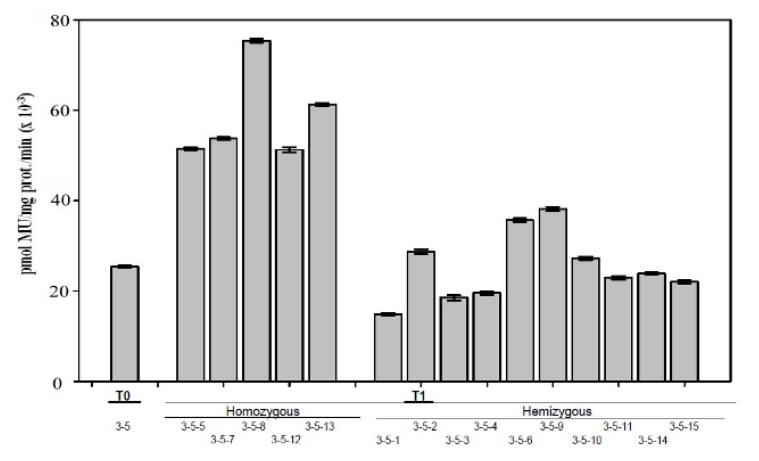

Figure 6 Specific activities of E1 enzyme in different organs. Specific activities of (A) E1 in the leaves of six independent T0 transgenic line (\#1 to \#6) and wild type (WT) rice plants, (B) in the mature seed (MS), green floret (F), leaf $(L)$, stem $(S)$ and root $(R)$ of T0 transgenic line \#3-5, and (C) in the leaves of some T1 plants of transgenic line \#3-5. Enzyme activity was assayed using a fluorescence spectrophotometer by its ability to cleave 4methylumbelliferyl $\beta$-D-cellobioside to produce the fluorophore, 4methylumbelliferne with peak excitation wavelength at $365 \mathrm{~nm}$ and peak fluorescence at $455 \mathrm{~nm}$. Data presented were means \pm standard error (bar) from three to four replicates of measurement. The activity was measured at $65^{\circ} \mathrm{C}$. Note both transgenic line \#4 and wild type (WT) had minimal activities.

reducing sugars than non-transgenic one, pulverized rice straw was subjected to enzymatic hydrolysis by concentrated cultured CGF containing xylanase. The amounts of reducing sugars, sucrose, glucose and fructose in the digestion media were monitored during digestion under different temperature conditions. Low amounts of these 


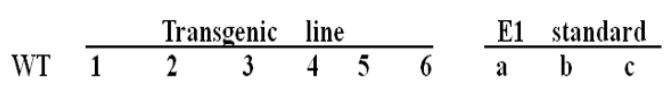

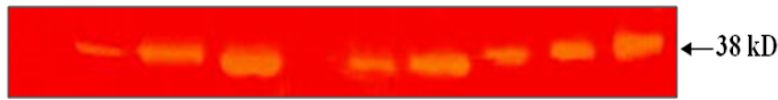

Figure 7 Zymogram analysis of E1 enzyme activity in the leaves. Total soluble protein was extracted from the leaves of six independent T0 transgenic lines (\#1 to \#6) and wild type (WT) rice plants and separated by SDS-PAGE in gel containing $0.1 \%$ carboxymethyl cellulose. After electrophoretic separation $(20 \mu \mathrm{g} /$ lane), the gel was washed and E1 activity stained in situ with Congo Red. The size of the clear zone indicates the degree of activity. Note that no E1 activity was detected in transgenic \#4 and wild type plants. Purified E1 protein was obtained by heating $\left(78^{\circ} \mathrm{C}\right)$ the leaf soluble protein extract of T0 transgenic line \#3-5 for $45 \mathrm{~min}$, and purified E1 protein: (A) $1 \mu \mathrm{g}$; (B) $2 \mu \mathrm{g}$; (C) $3 \mu \mathrm{g}$.

sugars were present in the air-dried rice straw samples of both wild type and E1 transgenic plants (homozygous plants of transgenic line \#3-5), artificial saliva (AS) and CGF (Figure 8). The AS was employed in an attempt to maintain the chemical compositions that approximate those of the CGF environment except for the hydrolytic enzymes. After incubation with AS at $39^{\circ} \mathrm{C}$ for $1 \mathrm{~h}, 39^{\circ} \mathrm{C}$ for $2 \mathrm{~h}$, or $39^{\circ} \mathrm{C}$ for $1 \mathrm{~h}$ plus $81^{\circ} \mathrm{C}$ for $1 \mathrm{~h}$, the amounts of the reducing sugars and non-reducing sugar (sucrose) released from both transgenic and non-transgenic wild type rice straw were low. The results indicate that the air dried rice straw from both genotypes contained low levels of reducing sugars and sucrose. There were increases in the amounts of sucrose, glucose and fructose after $1 \mathrm{~h}$ digestion at $39^{\circ} \mathrm{C}$, but the overall contents of these sugars remained low $(0.02 \mathrm{mg} / 10 \mathrm{mg}$ to 0.06 $\mathrm{mg} / 10 \mathrm{mg}$ dry weight). However, there were large increases in the amount of these sugars, except for fructose, from both wild type and transgenic rice straw samples at $39^{\circ} \mathrm{C}$ for $1 \mathrm{~h}$ and $39^{\circ} \mathrm{C}$ for $2 \mathrm{~h}$ when digested with CGF, which had xylanase activity; and the increases were most significant for transgenic rice straw, especially under the digestion condition of $39^{\circ} \mathrm{C}$ for $1 \mathrm{~h}$ plus $81^{\circ} \mathrm{C}$ for $1 \mathrm{~h}$. After digestion at $39^{\circ} \mathrm{C}$ for $1 \mathrm{~h}$, the additional 1 $\mathrm{h}$ digestion at $39^{\circ} \mathrm{C}$ only gave rise to a small increase in these sugars, while the most significant increases in reducing sugars, sucrose and glucose were found in transgenic rice straw after additional digestion at $81^{\circ} \mathrm{C}$ (an optimal temperature for E1 enzyme) for $1 \mathrm{~h}$. For example, for wild type rice straw the reducing sugar, sucrose and glucose contents (dry weight) increased from $3.32 \mathrm{mg} / 10 \mathrm{mg}$ to $3.51 \mathrm{mg} / 10 \mathrm{mg}$ (net increase $0.19 \mathrm{mg} / 10 \mathrm{mg}$ ), $0.036 \mathrm{mg} / 10 \mathrm{mg}$ to $0.069 \mathrm{mg} / 10 \mathrm{mg}$ (net increase $0.033 \mathrm{mg} / 10 \mathrm{mg}$ ) and $0.045 \mathrm{mg} / 10 \mathrm{mg}$ to $0.050 \mathrm{mg} / 10 \mathrm{mg}$ (net increase $0.005 \mathrm{mg} / 10 \mathrm{mg}$ ), respectively. On the other hand, for E1 transgenic rice straw, the corresponding increases for these sugars (dry weight) were from $3.73 \mathrm{mg} / 10 \mathrm{mg}$ to $4.83 \mathrm{mg} / 10 \mathrm{mg}$ (net increase $1.10 \mathrm{mg} / 10 \mathrm{mg}$ ), $0.041 \mathrm{mg} / 10 \mathrm{mg}$ to 0.076 $\mathrm{mg} / 10 \mathrm{mg}$ (net increase $0.035 \mathrm{mg} / 10 \mathrm{mg}$ ) and 0.117 $\mathrm{mg} / 10 \mathrm{mg}$ to $0.139 \mathrm{mg} / 10 \mathrm{mg}$ (net increase $0.022 \mathrm{mg} / 10$ $\mathrm{mg}$ ), respectively. Thus, relative to wild type rice straw, E1 transgenic rice straw released additional reducing sugars $(0.19 \mathrm{mg} / 10 \mathrm{mg}$ versus $1.10 \mathrm{mg} / 10 \mathrm{mg}$ dry weight) and glucose $(0.005 \mathrm{mg} / 10 \mathrm{mg}$ versus $0.022 \mathrm{mg} /$ $10 \mathrm{mg}$ dry weight) during this high temperature digestion, presumably due to the presence of $\mathrm{E} 1$ protein in its straw. Apparently, high temperature treatment increased the efficiency of cellulose hydrolysis through the action of the thermophilic E1 in the transgenic straw.

The presence of free sucrose in the straw could have contributed to the reducing sugars released during the hydrolysis experiment. However, our data showed that air-dried straw from both transgenic and wild type rice plants contained low amounts of reducing sugar, sucrose, glucose and fructose. This is consistent with data from a recent study by Park et al. [31], which showed that air-dried rice straw contained minimal amounts of sucrose and free glucose and fructose, presumably due to continued respiration and bacterial contamination during drying. Thus, our results demonstrate that, with a starting straw of $10 \mathrm{mg}$ dry matter, after $2 \mathrm{~h}$ incubation (at $39^{\circ} \mathrm{C}$ for $1 \mathrm{~h}$ plus $81^{\circ} \mathrm{C}$ for $1 \mathrm{~h}$ ) approximately $4.83 \mathrm{mg}$ and $3.52 \mathrm{mg}$ reducing sugars were released from the transgenic and wild type straw, respectively. After correcting for the background amount of reducing sugars in the CGF $(0.48 \mathrm{mg} / 10 \mathrm{mg})$ this $1.31 \mathrm{mg}$ of additional reducing sugars released through the action of $A$. cellulolyticus E1 in the transgenic rice straw represented a $43 \%$ increase. There were no corresponding increases in glucose and fructose, which may be related to the fact that digestion of cellulose by endoglucanase mainly releases cellobiose.

\section{Discussion}

Global rice production had reached 660 million dry metric tons in 2009, along with 800 million metric tons of straw, and continues to grow at a steady rate [32]. Rice straw contains a high cellulose content (approximately $45 \%$ ), and is a suitable resource for the largescale production of biofuels to replace fossil fuels and to reduce environmental pollution caused by agricultural wastes and burning of fossil fuels [33]. Use of cell walldegrading enzymes from microorganisms for the conversion of cellulosic material to sugars is a limiting step at present. Thus, large-scale production of effective cellulose hydrolytic enzymes is key to the biofuels industry. The expression of heterologous proteins in transgenic plants is an established technology. Consequently, the expression of foreign proteins has been successfully 


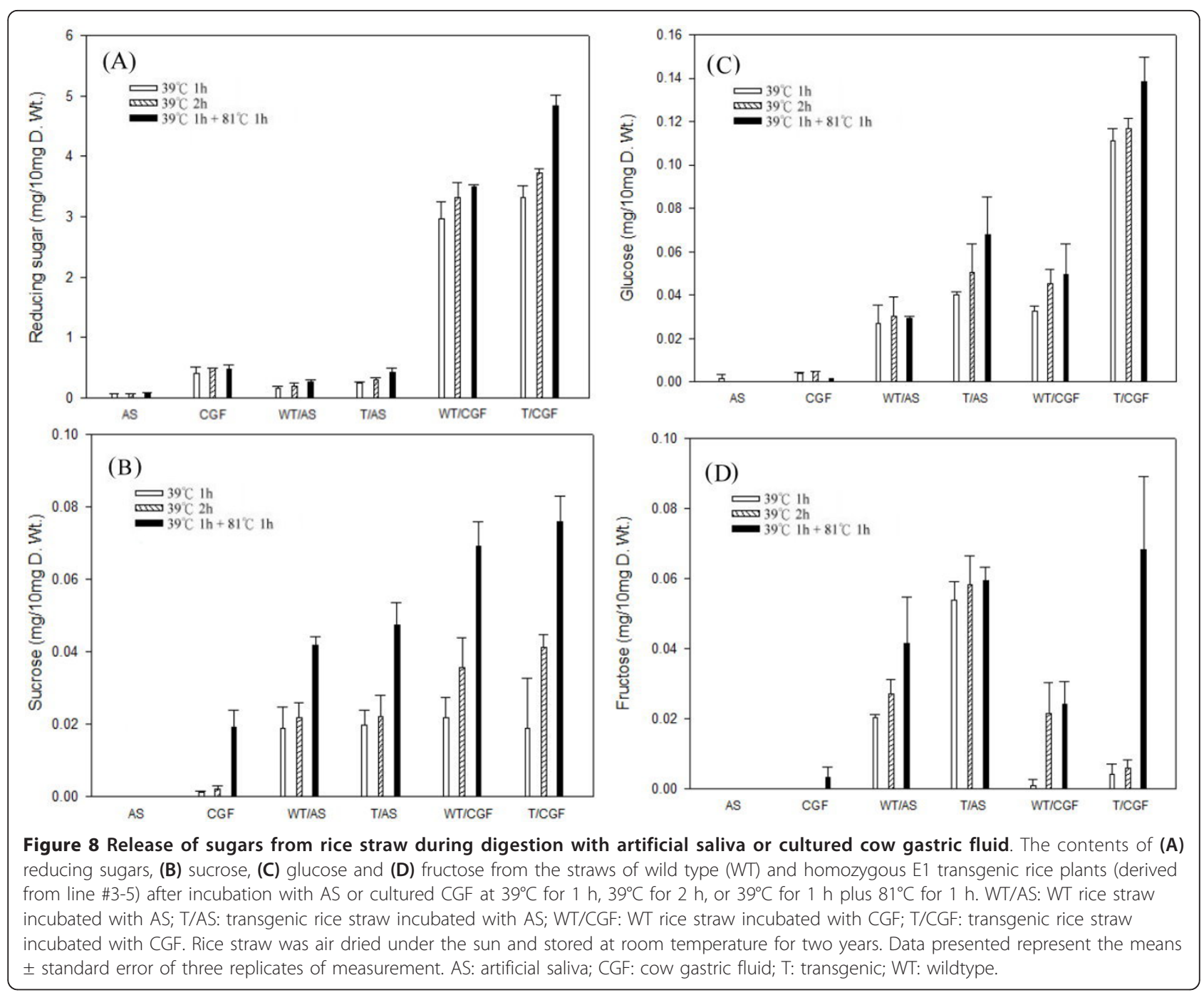

applied in plant systems at various levels, including industrially useful enzymes, viral proteins, pharmaceutical proteins, polypeptides (including antibodies) and various structural proteins [34-37]. The factors influencing the level of accumulation for each of these protein classes vary. Although success depends on the characteristics of the individual protein, protein accumulation has been particularly successful when targeted to the cell wall (apoplast compartment), vacuole or endoplasmic reticulum [11,38].

This study demonstrated that the $E 1$ gene of A. cellulolyticus integrated into the genome of transgenic rice plants (Figure 1) can be properly transcribed (Figures 2 and 3 ) and translated into an active enzyme and accumulated at high levels (Figures 4, 5, 6 and 7). We noticed that some of the transgenic rice plants with high E1 activities exhibited a short stature and flowered earlier than wild type plants. However, in a previous study, transgenic rice overexpressing $A$. cellulolyticus did not show any deleterious effect on plant growth and development [24]. The differences in E1 effect on rice plant growth and development between the present study and that of Oraby et al. [24] could in part stem from expression level. The highest expression level achieved in our transgenic lines was $6.1 \%$ of the total leaf soluble protein, higher than that reported by Oraby et al. [24]. The controversy regarding the effects of E1 on plant growth and development has been reported previously $[11,24]$. It also could be related to the difference in the primary structure of cell walls and its composition between monocot (rice) and dicot (tobacco) plants $[39,40]$ or the position effects of $E 1$ transgene insertion in the genome of transgenic plants. Further study is needed to address the effect of growth temperature on the growth and development of E1 transgenic rice. Most importantly, the E1 protein produced in rice retains its thermostability and can be purified by a simple heat treatment (Figure 5). Also significant is the fact 
that it remains active in tissues after a long period of storage at room temperature and the presence of E1 in the rice straw increases its hydrolytic efficiency (Figure 8).

The A. cellulolyticus E1 activity could be detected in all tissues of all five transgenic lines. Its activities in the leaves ranged from $60,000 \mathrm{pmol} \mathrm{MU} / \mathrm{mg}$ protein/min to $79,000 \mathrm{pmol} \mathrm{MU} / \mathrm{mg}$ protein/min in the homozygous plants derived from the line with the highest expression level (Figure 4). The large (ten-fold) variation in expression among the five transgenic lines containing E1 (Figure 4) was presumably a position effect, as all transgenic lines had one copy of insertion (Figure 1). This highlights the importance of generating as many transgenic plants as possible for selecting high expression lines with a normal phenotype. Transformation of rice with the E1 expression vector under the control of a constitutive Mac promoter [30] with the tobacco pathogenesis related signal peptide [21] allowed the heterologous E1 protein to be secreted to and accumulated in the apoplastic compartment at high levels. This is consistent with previous studies reporting that the apoplast can serve as a storage site for large quantities of functional foreign proteins [7]. Based on the zymogram PAGE (Figure 7) and western blot analysis data (Figure 4), E1 protein in all tissue extracts of the transgenic plants was partially degraded to its catalytic domain polypeptide of $38 \mathrm{kDa}$ (Figure 5), in agreement with the observation of previous studies $[7,23,41,42]$. Obviously, the degraded protein still retains its catalytic activity. The partial degradation of E1 protein may be due to the sensitivity of the cellulose-binding domain to proteases in plant extracts. Further study will be necessary to illustrate the E1 protein degradation pattern in plant tissues.

Although the Mac promoter is known to drive constitutive expression of transgenes in plants and the $E 1$ transcript was detected in all tissues, including the mature seed, floret, leaf, stem and root of transgenic rice (Figures 2,3,4B and $6 \mathrm{~B}$ ), much higher expression levels were found in green tissues, such as leaf, floret and stem (Figure 3). However, a relative large amount of E1 protein was detected in the root soluble protein sample in the western blot analysis (Figure 4B), but a relatively low E1 specific enzyme activity was found in the enzyme activity assay (Figure 6B). This is due to the fact that an equal amount of the total soluble protein for each sample was used in both analyses for comparison but root extract contains a relative low amount of other soluble protein and some potential inhibitors to the activity of E1. The highest amount of E1 protein accumulation, in the leaves of our transgenic rice plants, was up to $6.1 \%$ of the total leaf soluble protein (Figure 7 ), higher than the $4.9 \%$ in the transgenic rice plants reported by Oraby et al. [24], in which the cauliflower mosaic virus $35 \mathrm{~S}$ promoter was used to drive the expression of the bacterial $E 1$ gene in rice. Thus, the Mac promoter may be more effective for E1 protein production. However, the position of the gene insertion into the genome apparently has a strong influence on transgene expression. With a conservative estimate of ten metric tons of rice straw produced per hectare per year and a $5 \% \mathrm{E} 1$ protein content in the tissues, $30 \mathrm{~kg}$ of very pure E1 protein can be produced annually from a hectare of padding field.

The high thermostability and protease-resistance of $A$. cellulolyticus E1 protein allows the enzyme to remain active in the tissues for a long period of time. Most importantly, as demonstrated in the digestion experiment with cultured CGF (Figure 8), direct expression of A. cellulolyticus $\mathrm{E} 1$ in the transgenic rice straw increases the hydrolytic efficiency of cellulose during saccharification, which can reduce the amount of hydrolytic enzyme needed for the conversion of cellulosic biomass to fermentative sugars. A recent study with transgenic tobacco and maize suggests that the expression of $A$. cellulolyticus E1 during cell wall construction may alter the inherent recalcitrance of the cell wall [26]. All of these features show the great potential of using transgenic plants as a bioreactor for the large scale production of cellulases and reducing the cost for enzymes through tissue autohydrolysis.

\section{Conclusions}

With the anticipation of a fossil fuel shortage in the near future and awareness of the need for environment protection, the use of agricultural wastes and bioenergy crops for biofuel production is considered desirable. Genes coding for many cell wall degradation enzymes have been cloned and sequenced from a wide variety of microbes, and the application of plant genetic engineering in producing these enzymes for biofuel production from lignocellulose has received increasing attention and development in recent years. The most important goals of engineering plants in relation to bioenergy are to reduce the cost of biomass and cellulosic enzyme production and to produce effective cellulose decomposition enzymes on a large scale.

In this study, we adopted a transgene expression constructs that had been previously demonstrated improved A. cellulolyticus E1 expression in transgenic tobacco [21] for A. cellulolyticus E1 expression in transgenic rice, where the expression of the thermostable A. cellulolyticus E1 gene was under the control of a strong Mac promoter and pathogenesis related protein S signal peptide for apoplast targeting. High levels of A. cellulolyticus E1 protein in transgenic rice plants have been achieved via gene expression, driven by the strong Mac promoter, with accumulation in the apoplast 
compartment by a proper signal peptide. The bacterial gene was stably integrated into the rice genome, expressed and translated into active protein at high levels, especially in the leaf and stem, with a much higher enzyme activity than those obtained in previous studies. In the transgenic rice line with the highest expression level, the amount of $A$. cellulolyticus E1 protein accounted for $6.1 \%$ of the total soluble leaf protein with a specific activity of $79,000 \mathrm{pmol} \mathrm{MU} / \mathrm{mg}$ protein/ min. Most importantly, high levels of expression of this enzyme did not severely impair the plant growth and development of rice plants. This may be in part due to the high optimum temperatures $\left(81^{\circ} \mathrm{C}\right)$ for the E1 activity and the relatively low plant growth temperatures $\left(16^{\circ}\right.$ $\mathrm{C}$ to $35^{\circ} \mathrm{C}$ ), which may not activate the E1 enzyme substantially and interfere with the cell wall integrity of transgenic plants. Furthermore, the presence of highlevel active $A$. cellulolyticus E1 protein in the transgenic rice straw enhances the hydrolysis of cellulose to reducing sugars.

In the future, the advancement of plant genetic engineering can be tapped to produce biomass or crop plants with increased overall biomass and cellulose content, reduced lignin content [43] or simplified structure of hemicelluloses. It will also be interesting to simultaneously express both cellulose and hemicellulose degrading enzymes to increase the efficiency of cellulose and hemicellulose conversion into glucose and xylose, respectively. In addition, targeting the same or different foreign cellulose hydrolytic enzymes simultaneously to various cellular compartments of transgenic plants might provide the opportunity for effective production of large quantities of cellulases and increase the efficacy of tissue autohydrolysis. In short, with the advancements in modern plant genetic engineering, many cellulose hydrolysis-related genes from microbes have been cloned and introduced into plants and expressed as active proteins in large quantities. Modifying the genetic make-up for higher thermostability and protein stability during storage and for easy purification will also significantly lower the cost of cellulosic biofuel production.

\section{Methods}

\section{Transformation vector and bacterial strains}

The DNA fragment containing the apoplast transit peptide and mature E1 coding sequence from A. hydrolyticus $(1.56 \mathrm{~kb})$ was first fused in frame between the Mac promoter and nos terminator of the $p$ ZD264 vector [21]. For selection of transgenic plants, HptII was isolated from the binary vector $p$ CAMBIA1300 and inserted into the $p \mathrm{ZD} 264$ vector using the PmeI (GTTTAAAC) cloning site, which resulted in a vector of $p 1500$ for rice transformation (Figure 1). The primers used for polymerase chain reaction (PCR) to attach
HptII were 5'-CACACAACATACGAGCCGGAAGCAT3' and 5'-GCTTAGACAACTTAATAACACATTGCGGACGTT-3'. Escherichia coli strain DH5 $\alpha$ was used as the host for cloning plasmid DNA while Agrobacterium tumefaciens AGL0 strain harboring the vector was used for rice transformation.

\section{Plant material, gene transformation and plant growth conditions}

Immature embryos of a japonica rice cultivar (Oryza sativa L.), Tainoung 67 (TNG67), were used for induction of embryogenic calli. The Agrobacterium-mediated transformation and regeneration of transgenic plants were performed following the procedure of previous studies [44-48]. Regenerated transgenic rice plants were first cultured in a growth chamber under a day/night temperature regime of $28^{\circ} \mathrm{C} / 24^{\circ} \mathrm{C}$ and a light period of $14 \mathrm{~h}$ at $400 \mu \mathrm{mol} / \mathrm{m}^{2} / \mathrm{s}$. For molecular and biochemical studies, all transgenic and wild type rice pants were grown in a greenhouse under natural sun light conditions $(12 \mathrm{~h}-14 \mathrm{~h})$ with day temperature ranging from $25^{\circ}$ $\mathrm{C}$ to $32^{\circ} \mathrm{C}$ and night temperature from $20^{\circ} \mathrm{C}$ to $25^{\circ} \mathrm{C}$. Plants were watered and fertilized regularly.

\section{Isolation of rice genomic DNA}

For the isolation of genomic DNA, leaf tissues were ground in liquid nitrogen into a fine powder using a pestle and mortar and mixed with extraction buffer containing $100 \mathrm{mM}$ tris- $\mathrm{HC} 1$ (pH 7.5), $500 \mathrm{mM} \mathrm{NaCl}, 50$ $\mathrm{mM}$ ethylenediaminetetraacetic acid (EDTA), $2 \% \beta$-mercaptoethanol and 4\% sodium dodecyl sulfate (SDS) [49]. The mixture was incubated at $65^{\circ} \mathrm{C}$ for $15 \mathrm{~min}$ and centrifuged $(14,000 \mathrm{rpm})$ at room temperature for $3 \mathrm{~min}$. The supernatant was mixed with $5 \mathrm{M}$ potassium acetate and incubated at $-20^{\circ} \mathrm{C}$ for $15 \mathrm{~min}$. After centrifugation at $4^{\circ} \mathrm{C}$ for $20 \mathrm{~min}$, the supernatant was passed through a MILLEX-HA filter (Millipore, Billerica, MA, USA; pore diameter $0.45 \mu \mathrm{m}$ ), mixed gently with an equal volume of ice-cold isopropanol, and then incubated at $-20^{\circ} \mathrm{C}$ for $30 \mathrm{~min}$, followed by centrifugation at $4^{\circ} \mathrm{C}$ for $20 \mathrm{~min}$. The DNA pellet was washed with ethanol, air-dried and dissolved in $5 \times$ TE buffer $(50 \mathrm{mM}$ tris- $\mathrm{HCl}, 10 \mathrm{mM}$ EDTA, pH 8.0). One tenth volumes of $3 \mathrm{M}$ sodium acetate and an equal volume of isopropanol were added and mixed well. After centrifugation at $4{ }^{\circ} \mathrm{C}$ for $10 \mathrm{~min}$, the DNA pellet was washed sequentially by $70 \%$ and $95 \%$ ethanol, air-dried, and then dissolved in distilled water.

\section{Southern blot analysis}

Southern blot analysis was performed essentially as described by Sambrook et al. [49]. Genomic DNA was first treated with RNase A at $60^{\circ} \mathrm{C}$ for $2 \mathrm{~h}$. Twenty-five micrograms DNA was digested by HindIII, and DNA fragments separated by electrophoresis on $0.8 \%$ agarose 
gel at $25 \mathrm{~V}$ for $15 \mathrm{~h}$. After electrophoresis, the agarose gel was first soaked in $0.25 \mathrm{M} \mathrm{HCl}$ for $15 \mathrm{~min}$ for depurination, denatured by soaking in the denature solution containing $0.5 \mathrm{~N} \mathrm{NaOH}$ and $1 \mathrm{M} \mathrm{NaCl}$ for $2 \mathrm{~h}$, and then neutralized in $0.5 \mathrm{M}$ tris- $\mathrm{HCl}(\mathrm{pH} 7.4)$ and 2.5 $\mathrm{M} \mathrm{NaCl}$ for $2 \mathrm{~h}$. The DNA was transferred to Hybond$\mathrm{N}+$ membrane (Amersham Biosciences, Little Chalfont, Buckinghamshire) by capillary transfer using $10 \times$ SSC buffer that contains $1.5 \mathrm{M}$ sodium chloride and $0.15 \mathrm{M}$ sodium citrate, $\mathrm{pH} 7.0$ and subsequently fixed by UV cross-linking. Probes were prepared from the PCR products of E1 and HptII independently using genomic DNA isolated from transgenic rice plants as templates. About $200 \mu \mathrm{g}$ of PCR products and $0.5 \mu \mathrm{g}$ of random primers were mixed and denatured at $94^{\circ} \mathrm{C}$ for $3 \mathrm{~min}$. Denatured PCR products were diluted to a final volume of $15 \mu \mathrm{L}$ in Klenow buffer mixture containing $6 \mu \mathrm{g}$ of BSA, $0.1 \mathrm{mM}$ deoxyribonucleotide triphosphate without deoxycytidine triphosphate (dCTP) and 5 units of Klenow fragments of DNA polymerase I, kept at room temperature for $1 \mathrm{~h}$ after adding ${ }^{32} \mathrm{P}$-labeled deoxycytidine triphosphate, and then passed through a Sephadex G50 column (Sigma-Aldrich, St. Louis, MO, USA) to purify the probe. The membrane was treated with pre-hybridization solution containing $1 \mathrm{M} \mathrm{NaCl}, 10 \%$ sodium chloride-tris-EDTA buffer (SSTE), $1 \times$ Denhardt's solution, $0.085 \%$ dextran sulfate and $1 \%$ salmon sperm DNA at $42^{\circ} \mathrm{C}$ for $4 \mathrm{~h}$, and then hybridized with the probe at $42^{\circ} \mathrm{C}$ overnight. The hybridized membrane was washed sequentially by $0.1 \times \mathrm{SSC}$ containing $0.1 \% \mathrm{SDS}$ at $42^{\circ} \mathrm{C}$ for $20 \mathrm{~min}$, and exposed to X-ray film at $-80^{\circ} \mathrm{C}$ for a period of time ranging from $8 \mathrm{~h}$ to 2 weeks, depending on radioactivity.

\section{RNA extraction and northern blot analysis}

Total RNA was extracted according to Wang and Vodkin [50] with a modified phenol/chloroform protocol. Leaf tissues were ground in liquid nitrogen with TENS buffer, containing $80 \mathrm{mM}$ tris- $\mathrm{HCl}, 16 \mathrm{mM}$ EDTA, 160 $\mathrm{mM} \mathrm{NaCl}, 4 \%$ SDS and $16 \mathrm{mM}$ dithiothreitol (DTT). Reverse transcriptase-PCR was performed as described by Chen et al. [51] with slight modification. Total RNA $(7.5 \mu \mathrm{g})$ was first treated with RNase-free DNase I by incubating in a mixture containing $6.7 \mathrm{mM}$ DTT, 20 units RNAsin and 1 unit RNase-free DNase I. The mixture was mixed evenly and incubated at $37^{\circ} \mathrm{C}$ for $15 \mathrm{~min}$ and then at $80^{\circ} \mathrm{C}$ for $10 \mathrm{~min}$ [52].

RNA gel blot analysis was performed as described by Chao et al. [53]. Total RNA was treated with 3-(N-morpholino)propanesulfonic acid buffer, containing $5 \%$ formaldehyde and $40 \%$ formamide, and separated by electrophoresis on $1.2 \%$ agarose gel. Total RNA in the gel was stained with ethidium bromide and then treated with $50 \mathrm{mM} \mathrm{NaOH}$ for $30 \mathrm{~min}$, followed by $10 \times \mathrm{SSC}$ for $30 \mathrm{~min}$. The RNA was then transferred to a Hybond-N+ membrane by capillary transfer using $10 \times$ SSC and then fixed onto the membrane by UV crosslinking. Probe preparation and hybridization procedures were the same as described for Southern blot analysis.

\section{Enzyme activity assay}

Soluble protein was extracted from newly matured leaf, stem, root, green floret and mature seeds of transgenic and wild type plants by grinding in cold extracting medium containing $80 \mathrm{mM}$ 2-(N-morpholino)ethanesulfonic acid (MES, pH 5.5), $10 \mathrm{mM} \beta$-mercaptoethanol, $10 \mathrm{mM}$ EDTA, $0.1 \%$ sodium $\mathrm{N}$-lauroylsarcosinate $(\mathrm{w} / \mathrm{v}), 0.1 \%$ Triton X-100 (v/v), $1 \mathrm{mM}$ phenylmethylsulfonyl fluoride (PMSF), $10 \mu \mathrm{M}$ leupeptin, and $1 \mu \mathrm{g} / \mathrm{mL}$ pepsin $\mathrm{A}$. The crude extract was centrifuged at $15,000 \mathrm{~g}$ for $10 \mathrm{~min}$ at $4^{\circ} \mathrm{C}$ and the supernatant was used immediately for enzyme assay. Endoglucanase activity was quantitated by its ability to cleave 4-methylumbelliferyl- $\beta$-D-cellobioside (MUC) to produce the fluorophore, 4-methylumbelliferone (4-MU), at $65^{\circ} \mathrm{C}$ [7]. The reaction was initiated by adding $50 \mu \mathrm{L}$ enzyme extract with an equal volume of $2 \times$ ice cold endoglucanase activity assay buffer containing $4 \mathrm{mM}$ 4-MUC, $160 \mathrm{mM}$ MES (pH 5.5), $20 \mathrm{mM}$ $\beta$-mercaptoethanol, $2 \mathrm{mM}$ EDTA, and $2 \mathrm{mM}$ DTT, heated to $65^{\circ} \mathrm{C}$, and terminated after $45 \mathrm{~min}$ by adding $0.2 \mathrm{M} \mathrm{Na}_{2} \mathrm{CO}_{3}$. The peak excitation wavelength was 365 $\mathrm{nm}$ and the peak fluorescence emission was $455 \mathrm{~nm}$, measured with a TECAN infinite M200 fluorescence spectrophotometer (Tecan, Gordig/Salzburg, Austria). Enzyme specific activity was expressed on a total soluble protein basis.

\section{Antibody production}

For the production of polyclonal antibodies against E1, the coding sequence of mature E1 was PCR amplified with $p 1500$ as a template using a gene specific primer set (forward, 5'-AAGCTTGCGGGCGGCGGCTATTGGCACACGA-3'; reverse, 5' CTCGAGTGTCGGTGCCGCGTTGCTTCCGGTA-3') with HindIII/XhoI restriction sites. The resulting PCR product was digested with HindIII and XhoI, and inserted into the prokaryote His-tag expression vector $p$ QEtrisystem (Invitrogen, Valencia, CA, USA) to construct the $p$ TRI/E1 vector. $E$. coli strain BL21 was used for the production of recombinant protein, and overexpression of the truncated protein was induced according to the manufacturer's instructions. The E1 protein from the sonicated cell extract was primarily purified by TALON metal affinity resin (Clontech, Mountain View, CA, USA) and further separated by electrophoresis on 10\% SDS-PAGE. Rabbits were immunized with $100 \mu \mathrm{g}$ of protein in the first injection with four booster injections at one-week intervals, each with $50 \mu \mathrm{g}$ of protein. 
After clearance by centrifugation, the crude serum obtained from the rabbits was used for immunological studies. For antibody titer determination, purified E1protein was separated on 10\% SDS gels and blotted onto polyvinylidene fluoride (PVDF) membranes (BioRad, Hercules, CA, USA) with electrophoresis. The blots were incubated with the antibody with a series of dilution, and immunodetection was carried out using alkaline phosphatase conjugated goat anti-rabbit immunoglobulin G.

\section{SDS-PAGE, western blot and zymography}

The total soluble protein was extracted from newly matured leaves by the same method as described above for enzyme assay. The protein concentration was determined using Quick Start Bradford Protein Assay (BioRad, Hercules, CA, USA) with BSA as standard according to the instruction manual. The lanes were loaded with $20 \mu \mathrm{g}$ of proteins per lane was loaded onto $10 \%$ polyacrylamide gel and separated by electrophoresis [54]. The protein on the gel was transferred on to PVDF membrane (Bio-Rad, Hercules, CA, USA) with electrophoresis, and probed with rabbit antibodies against purified E1 (1:100,000 dilution) and tobacco Rubisco large subunit independently. Goat anti-rabbit immunoglobulin G conjugated to alkaline phosphatase was used as a second antibody. Color formation was developed by adding 5-bromo-4-chloro-3'-indolyphosphate p-toluidine salt/ nitro-blue tetrazolium chloride (BCIP/NBT) substrate solution (Sigma-Aldrich, St. Louis, MO, USA) directly onto the membrane at room temperature.

The assay of E1 activity by a zymogram was performed with leaf soluble protein separated in $10 \%$ polyacrylamide gel containing $0.1 \%$ CMC according to Chavez et al. [55] with minor modifications. After electrophoresis, the gel was washed with $50 \mathrm{mM}$ phosphatebuffered saline ( $\mathrm{pH} 5.3$ ) for $30 \mathrm{~min}, 2.5 \%$ triton $\mathrm{X}-100$ for $4 \mathrm{~h}$ and incubated at $65^{\circ} \mathrm{C}$ in $50 \mathrm{mM}$ phosphate-buffered saline for $30 \mathrm{~min}$. The gel was stained in $1 \%$ Congo red solution for $15 \mathrm{~min}$ at room temperature, and then washed with $1 \mathrm{M} \mathrm{NaCl}$ to enable visualization of cleared zones, which correspond to the E1 endoglucanase activity. The amount of E1 protein accumulated in the leaves among transgenic plants was estimated with QuantOne software v4.3.0 (BioRad, Hercules, CA, USA) based on the densitometric determination from the zymogram, where the purified E1 protein at $1 \mu \mathrm{g}, 2 \mu \mathrm{g}$ and $3 \mu \mathrm{g}$ per lane were included as standards.

\section{Hydrolysis of rice straw with cultured CGF}

Fresh CGF was collected from a local abattoir, quickly strained through four layers of cheesecloth, mixed with AS in a $1: 5$ ratio $(\mathrm{v} / \mathrm{v})$ and incubated statically at $39^{\circ} \mathrm{C}$ in flasks under anaerobic condition by flushing with
$\mathrm{CO}_{2}$ gas. The AS was based on McDougall buffer [56], which contained $117 \mathrm{mM} \mathrm{NaHCO}_{3}, 26 \mathrm{mM} \mathrm{Na}_{2} \mathrm{HPO}_{4}$. $12 \mathrm{H}_{2} \mathrm{O}, 8 \mathrm{mM} \mathrm{NaCl}, 8 \mathrm{mM} \mathrm{KCl}, 0.2 \mathrm{mM} \mathrm{CaCl}_{2}, 0.3$ $\mathrm{mM} \mathrm{MgCl}_{2}$ (pH 8.1). The AS also contained 2\% napier grass powder as the sole carbon source. A repeatedbatch culture was conducted. After 2 days of incubation, the culture medium was centrifuged $(3,200 \mathrm{~g}, 30 \mathrm{~min})$ and the supernatant was used as inoculums for the next culture. The supernatant of the fifth repeated-batch culture was collected, concentrated five times and stored at $-20^{\circ} \mathrm{C}$ until use. The activities of xylanase, cellulase and avicelase in the concentrated supernatant were analyzed based on the amount of liberated reducing sugars by the 3,5-dinitrosalicylic acid method [57-60]. The concentrated supernatant contained approximately $18 \mathrm{U}$ xylanase per $\mathrm{mL}$, and no cellulase activity was detected. The 200- $\mu \mathrm{L}$ reaction mixture contained the same amount of the concentrated supernatant in buffer $\mathrm{pH} 8.0$ and 1\% $(\mathrm{w} / \mathrm{v})$ of the corresponding substrates: birch wood xylan for xylanase activity, CMC for CMCase activity, and avicel for avicelase activity. The reactions were incubated at $39^{\circ} \mathrm{C}$ for $10 \mathrm{~min}$ and the amount of reducing sugar was determined by absorbance measurements based on standard curves prepared using the corresponding sugars. One unit was defined as the amount of enzyme liberating $1 \mu \mathrm{mol}$ of reducing sugar, or the corresponding products, per minute under the assay conditions.

For enzymatic hydrolysis of the rice straw, rice straw was harvested without grains at mature stage and dried in air. The entire straw was milled into fine powder (passed through a $1 \mathrm{~mm}$ mesh), and $0.1 \mathrm{~g}$ straw sample was mixed with $10 \mathrm{~mL}$ AS or $10 \mathrm{~mL}$ concentrated supernatant of the cultured $\mathrm{CGF}$, and incubated at $39^{\circ} \mathrm{C}$ for $1 \mathrm{~h}, 39^{\circ} \mathrm{C}$ for $2 \mathrm{~h}$, or $39^{\circ} \mathrm{C}$ for $1 \mathrm{~h}$ plus $81^{\circ} \mathrm{C}$ for $1 \mathrm{~h}$. Each experiment was repeated three times. The amount of sugars released during $1 \mathrm{~h}$ and $2 \mathrm{~h}$ incubations was determined using a 3,5-dinitrosalicylic acid method, with D-glucose as standard. A Mixed Sucrose-D-fructose- D-glucose Assay Kit (Megazyme, Wicklow, Ireland) was used for quantification of free glucose, sucrose and fructose, according to the manufacture's instructions.

\section{Abbreviations}

AS: artificial saliva; BSA: bovine serum albumin; CGF: cow gastric fluid; CMC: carboxymethyl cellulose; DTT: dithiothreitol; E1: cellulose hydrolytic enzyme $\beta$-1, 4-endoglucanase; EDTA: ethylenediaminetetraacetic acid; kDa: kiloDaltons; MES: 2-(N-morpholino)ethanesulfonic acid; MUC: 4methylumbelliferyl- $\beta$-D-cellobioside; PVDF: polyvinylidene fluoride; salinesodium citrate.

\section{Acknowledgements}

This work was supported in part by funds from the Council of Agriculture (97AS-1.2.1-ST-a2) and National Science Council of Taiwan (NSC 99-ET-415001-ET). We also thank Yi-Chin Wang and Jiun-Hau Lu for the analysis of reducing sugars. Ziyu Dai was supported by the DOE Office of Biomass. The 
authors also thank Ms. Kathryn S. Panther of Pacific Northwest National Laboratory (PNNL) for her support in construction of transgene expression vector. PNNL is multiprogram national laboratory operated by Battelle for the DOE under Contract No. DE-AC05-76RLO 1830.

\section{Author details}

${ }^{1}$ Institute of Bioagricultural Science, National Chiayi University, Chiayi, 60004 Taiwan. ${ }^{2}$ Fungal Biotechnology Team, Chemical and Biological Processing Development Group, Pacific Northwest National Laboratory, Richland, WA, 99352, USA. ${ }^{3}$ Departmet of Microbiology, Immunology and Biopharmaceuticals, National Chiayi University, Chiayi, 60004 Taiwan. ${ }^{4}$ School of Biological Sciences, Washington State University, Pullman, WA 99164-4238, USA.

\section{Authors' contributions}

HLC conducted the rice transformation and characterized the molecular and biochemical properties of transgenic rice. HLC and MSBK designed the experiments, analyzed the data and wrote the paper. CWH performed enzymatic hydrolysis of rice straw by cow gastric fluid. ZD constructed the transgene expression vector, analyzed the results and reviewed the manuscript.

\section{Competing interests}

The authors declare that they have no competing interests.

Received: 6 August 2011 Accepted: 10 December 2011 Published: 10 December 2011

\section{References}

1. Zhang YH: Reviving the carbohydrate economy via multi-product lignocellulose biorefineries. J Ind Microbiol Biotechnol 2008, 35:367-375.

2. Himmel ME, Ding SY, Johnson DK, Adney WS, Nimlos MR, Brady JW, Foust TD: Biomass recalcitrance: engineering plants and enzymes for biofuels production. Science 2007, 315:804-807.

3. Lynd LR, Laser MS, Bransby D, Dale BE, Davison B, Hamilton R, Himmel M, Keller M, McMillan JD, Sheehan J, Wyman CE: How biotech can transform biofuels. Nature Biotech 2008, 26:169-172.

4. Ward OP, Singh A: Bioethanol technology: developments and perspectives. Adv Appl Microbiol 2002, 51:53-80.

5. Bayer EA, Chanzy H, Lamed R, Shoham Y: Cellulose, cellulases and cellulosomes. Curr Opin Struct Biol 1998, 8:548-557.

6. Abramson M, Shoseyov O, Shani Z: Plant cell wall reconstruction toward improved lignocellulosic production and processability. Plant Science 2010, 178:61-72.

7. Ziegler MT, Thomas SR, Danna KJ: Accumulation of a thermostable endo1,4- $\beta$-D-glucanase in the apoplast of Arabidopsis thaliana leaves. Mol Breed 2001, 6:37-46.

8. Pauly M, Keegstra K: Cell-wall carbohydrates and their modification as a resource for biofuels. Plant J 2008, 54:559-568.

9. FAO.org: Agriculture Statistics $>$ Grains $>$ Rice production (2009) by country., http://faostat.fao.org. Accessed 6 June 2010.

10. Yang B, Dai Z, Ding S, Wyman CE: Enzymatic hydrolysis of cellulosic biomass: a review. Biofuels 2011, 2:421-450.

11. Taylor LE II, Dai Z, Decker SR, Brunecky R, Adney WS, Ding S, Himmel ME: Heterologous expression of glycosyl hydrolases in planta: a new departure for biofuels. Trends in Biotech 2008, 26:413-424.

12. Jiang XR, Liu JW, Li WL: The progress in thermophile research and its application prospect in cellulosic ethanol. Life Sci Res 2010, 5:449-455.

13. Sticklen M: Plant genetic engineering to improve biomass characteristics for biofuels. Curr Opin Biotechnol 2006, 17:315-319.

14. Wei S, Marton I, Dekel M, Shalitin D, Lewinsohn E, Bravdo BA, Shoseyov O: Manipulating volatile emission in tobacco leaves by expressing Aspergillus nigerbeta-glucosidase in different subcellular compartments. Plant Biotechnol I 2004, 2:341-350.

15. Gray BN, Yang H, Ahner BA, Hanson MR: An efficient downstream box fusion allows high-level accumulation of active bacterial $\beta$-glucosidase in tobacco chloroplasts. Plant Mol Biol 2011, 76:345-355.

16. Buanafina MM, Langdon T, Hauck B, Dalton S, Timms-Taravella E, Morris P: Targeting expression of a fungal ferulic acid esterase to the apoplast, endoplasmic reticulum or golgi can disrupt feruloylation of the growing cell wall and increase the biodegradability of tall fescue (Festuca arundinacea). Plant Biotechnol J 2010, 8:316-331.

17. Harholt J, Bach IC, Lind-Bouquin S, Nunan KJ, Madrid SM, BrinchPedersen H, Holm PB, Scheller HV: Generation of transgenic wheat (Triticum aestivum L.) accumulating heterologous endo-xylanase or ferulic acid esterase in the endosperm. Plant Biotechnol J 2010, 8:351-362.

18. Gray BN, Bougri O, Carlson AR, Meissner J, Pan S, Parker MH, Zhang D, Samoylov V, Ekborg NA, Michael Raab R: Global and grain-specific accumulation of glycoside hydrolase family 10 xylanases in transgenic maize (Zea mays). Plant Biotechnol J 2011, 9:1100-1108.

19. Hood EE, Love R, Lane J, Bray J, Clough R, Pappu K, Drees C, Hood KR, Yoon S, Ahmad A, Howard JA: Subcellular targeting is a key condition for highlevel accumulation of cellulase protein in transgenic maize seed. Plant Biotechnol I 2007, 5:709-719.

20. Harrison MD, Geijskes J, Coleman HD, Dale JL: Accumulation of recombinant cellobiohydrolase and endoglucanase in the leaves of mature transgenic sugar cane. Plant Biotechnol J 2011, 9:884-896.

21. Dai Z, Hooker BS, Anderson DB, Thomas SR: Improved plant-based production of E1 endoglucanase using protato: expression optimization and tissue targeting. Mol Breed 2000, 6:277-285.

22. Dai Z, Hooker BS, Anderson DB, Thomas SR: Expression of Acidothermus cellulolytics endoglucanse E1 in transgenic tobacco: biochemical characteristic and physiological effects. Transgenic Res 2000, 9:43-54.

23. Biswas GCG, R C, Sticklen M: Expression of biologically active Acidothermus cellulolyticus endoglucanase in transgenic maize plants. Plant Science 2006, 171:617-623.

24. Oraby H, Venkatesh B, Dale B, Ahmad R, Ransom C, Oehmke J, Sticklen M: Enhanced conversion of plant biomass into glucose using transgenic rice- produced endoglucanase for cellulosic ethanol. Transgenic Res 2007, 16:739-749.

25. Ziegelhoffer T, Raasch JA, Phillips SA: Dramatic effects of truncation and sub-cellular targeting on the accumulation of recombinant microbial cellulase in tobacco. Mol Breed 2001, 8:147-158.

26. Brunecky R, Michael JS, Vinzant TB, Himmel ME, Lee D, Blaylock MJ, Decker SR: In planta expression of A. cellulolyticus Cel5A endocellulase reduces cell wall recalcitrance in tobacco and maize. Biotechnol Biofuels 2011, 4:1-10

27. Conrad U, Fiedler U: Compartment-specific accumulation of recombinant immunoglobulins in plant cells: an essential tool for antibody production and immunomodulation of physiological functions and pathogen activity. Plant Mol Biol 1998, 38:101-109.

28. Twyman RM, Stoger E, Schillberg S, Christou P, Fischer R: Molecular farming in plants: host systems and expression technology. Trends Biotechnol 2003, 21:570-578.

29. Tucker MP, Mohagheghi A, Grohmann K, Himmel ME: Ultra-thermostable cellulases from Acidothermus cellulolyticus: comparison of temperature optima with previously reported cellulases. Nat Biotech 1989, 7:817-820.

30. Comai L, Moran P, Maslyar D: Novel and useful properties of a chimeric plant promoter combining CaMV $35 \mathrm{~S}$ and MAS elements. Plant Mol Biol 1990, 15:373-381.

31. Park JY, Seyama T, Shiroma R, Ike M, Srichuwong S, Nagata K, Arai-Sanoh Y, Kondo M, Tokuyasu K: Efficient recovery of glucose and fructose via enzymatic saccharification of rice straw with soft carbohydrates. Biosci Biotechnol Biochem 2009, 73:1072-1077.

32. Domínguez-Escribá L, Porcar M: Rice straw management: the big waste. Biofuels, Bioproducts Biorefining 2009, 4:154-159.

33. Wyman CE, Dale BE, Elander RT, Holtzapple M, Ladisch MR, Lee YY, Mitchinson C, Saddler JN: Comparative sugar recovery and fermentation data following pretreatment of poplar wood by leading technologies. Biotechnol Prog 2009, 25:333-339.

34. Witcher DR, Hood EE, Peterson D, Bailey M, Bond D, Kusnadi A, Evangelista R, Nikolov Z, Wooge C, Mehigh R, Kappel W, Register I, Howard JA: Commercial production of $\beta$-glucuronidase (GUS). A model system for the production of proteins in plants. Mol Breed 1998, 4:301-312.

35. Streatfield SJ, Jilka JM, Hood EE, Turner DD, Bailey MR, Mayor JM, Woodard SL, Beifuss KK, Horn ME, Delaney DE: Plant-based vaccines: unique advantages. Vaccine 2001, 19:2742-2748.

36. Streatfield SJ, Mayor JM, Barker DK, Brooks C, Lamphear BJ, Woodard SL, Beifuss KK, Vicuna D, Massey LA, Horn ME, Delaney DE, Nikolov ZL, Hood EE, Jilka JM, Howard JA: Development of an edible subunit vaccine 
37. Woodard SL, Mayor JM, Bailey MR, Barker DK, Love RT, Lane JR, Delaney DE, McComas-Wagner JM, Mallubhotla HD, Hood EE: Maize (Zea mays)-derived bovine trypsin: characterization of the first large-scale, commercial protein product from transgenic plants. Biotechnol Appl Biochem 2003, 38:123-130.

38. Streatfield SJ: Approaches to achieve high-level heterologous protein production in plants. Plant Biotechnol J 2007, 5:2-15.

39. Burke D, Kaufman P, Mcneil M, Albersheim P: The structure of plant cell walls. Plant Physiol 1974, 54:109-115.

40. Vogel J: Unique aspects of the grass cell wall. Curr Opin Plant Biol 2008, 11:301-307.

41. Dai Z, Hooker BS, Quesenberry RD, Thomas SR: Optimization of Acidothermus cellulolyticus endoglucanase (E1) production in transgenic tobacco plants by transcriptional, post-transcription and posttranslational modification. Transgenic Res 2005, 14:627-643.

42. Hood EE, Love R: Subcellular targeting is a key condition for high-level accumulation of cellulase protein in transgenic maize seed. Plant Biotechnol J 2007, 5:709-719.

43. Chen F, Dixon RA: Lignin modification improves fermentable sugar yields for biofuel production. Nat Biotechnol 2007, 25:759-761.

44. Chan MT, Chang HH, Ho SL, Tong WF, Yu SM: Agrobacterium-mediated production of transgenic rice plants expressing a chimeric a-amylase promoter/B-glucuronidase gene. Plant Mol Biol 1993, 22:491-506.

45. Rashid H, Yokoi S, Toriyama K, Hinata K: Transgenic plant production mediated by Agrobacterium in indica rice. Plant Cell Rep 1996, 15:727-730.

46. Hiei Y, Ohta S, Komari T, Kumashiro T: Efficient transformation of rice (Oryza sativa L.) mediated by Agrobacterium and sequence analysis of the boundaries of the T-DNA. Plant J 1994, 6:271-282.

47. Toki S: Rapid and efficient Agrobaterium-mediated transformation in rice. Plant Mol Biol Rep 1997, 15:16-21.

48. Kumar KK, Maruthasalam S, Loganathan M, Sudhakar D, Balasubramanian P: An improved Agrobacterium-mediated transformation protocol for recalcitrant elite indica rice cultivars. Plant Mol Biol Rep 2005, 23:67-73.

49. Sambrook J, Fritsch EF, Maniatis T: Molecular Cloning - A Laboratory Manual. New York, USA: Cold Spring Habour Laboratory Pressi, 21989.

50. Wang CS, Vodkin LO: Extraction of RNA from tissues containing high levels of procyanidins that bind RNA. Plant Mol Biol Rep 1994, 12:132-145.

51. Chen PW, Chiang CM, Tseng TH, YU SM: Interaction between rice MYBGA and the gibberellin response element controls tissue-specific sugar sensitivity of a-amylase genes. Plant Cell 2006, 18:2326-2340.

52. McElroy $D$, Rothenberg $M$, Wu R: Structural characterization of a rice actin gene. Plant Mol Biol 1990, 14:163-171.

53. Chao YC, Wood HA, Chang CY, Lee HJ, Shen WC, Lee HT: Differential expression of $\mathrm{Hz}-1$ baculovirus genes during productive and persistent viral infections. J Virol 1992, 66:1442-1448.

54. Dai Z, Ku MSB, Zhang D, Edwards GE: Effects of growth regulators on the induction of Crassulacean acid metabolism in the facultative halophyte Mesembryaanthemum crystallinum L. Planta 1994, 192:287-294.

55. Chavez R, Schachter K, Navarro C, Peirano A, Aguirre C, Bull P, Eyzaguirre J: Differences in expression of two endoxylanase genes (xynA and xynB) from Penicillium purpurogenum. Gene 2002, 293:161-168.

56. McDougall El: Studies on ruminant saliva. 1. The composition and output of sheep's saliva. Biochem J 1948, 43:99-109.

57. Khanna SG: Regulation, purification, and properties of xylanase from Cellulomanas fimi. Enzyme Microb Technol 1993, 15:990-995.

58. Woodward J, Lima M, Lee NE: The role of cellulase concentration in determining the degree of synergism in the hydrolysis of microcrystalline cellulose. Biochem J 1988, 255:895-899.

59. Miller GL: Use of dinitrosalicylic acid reagent for determination of reducing sugars. Anal Biochem 1959, 31:426-428.

60. Dhillon A, Gupta JK, Jauhari BM, Khanna S: A cellulase-poor, thermostable, alkalitolerant xylanase produced by Bacillus circulans AB 16 grown on rice straw and its application in biobleaching of eucalyptus pulp. Bioresour Technol 2000, 73:273-277.

doi:10.1186/1754-6834-4-58

Cite this article as: Chou et al: High level expression of Acidothermus cellulolyticus $\beta-1$, 4-endoglucanase in transgenic rice enhances the hydrolysis of its straw by cultured cow gastric fluid. Biotechnology for Biofuels 2011 4:58.

\section{Submit your next manuscript to BioMed Central and take full advantage of:}

- Convenient online submission

- Thorough peer review

- No space constraints or color figure charges

- Immediate publication on acceptance

- Inclusion in PubMed, CAS, Scopus and Google Scholar

- Research which is freely available for redistribution

Submit your manuscript at www.biomedcentral.com/submit 